\title{
Use of Artificial Intelligent in Learning Management System (LMS): A Systematic Literature Review
}

\author{
Nouf S. Aldahwan \\ Department of Information Systems \\ King Khalid University, Abha, Saudi Arabia
}

\author{
Nourah I. Alsaeed \\ Computing and Information Technology \\ King Abdulaziz University, Jeddah, Saudi Arabia
}

\begin{abstract}
Learning Management System (LMS) represents the best way to provide educational content in higher education settings by supplying worldwide students with high-quality educational material. Student-teacher learning management programs are implemented as an intermediary. This paradigm is changed by intelligent agents reproducing the smart procedures of the instructor and the students. The technologies of Artificial Intelligence are based upon the replication of human intelligence concepts. This study presents an overview of the LMS in which Artificial Intelligent techniques were used. In addition, we highlight other the wide range of variety Models in Learning Management Systems related to AI were studied to solve some LMS issues and benefit students, faculty members, and administrators.
\end{abstract}

\section{Keywords}

Artificial Intelligence, Learning Management System, Model, Issues.

\section{INTRODUCTION}

AI can contribute to social learning by supporting integrated group training based on learner models, by facilitating online community engagement or by summarizing conversations that would be used by a human instructor to lead students towards the goals and objectives of a course [1].

What are future areas of AI applications in education, and in particular higher education, despite this definition of AI? Today, three types of educational AI software applications are available: a) individual tutors, b) smart collaborative learning support, and c) smart, augmented reality; there needs to be support and regulation of online cooperation. AI can contribute to social learning by supporting integrated group training based on learner models, by facilitating online community engagement or by summarizing conversations that would be used by a human instructor to lead students towards the goals and objectives of a course [1].

An LMS is a software system that allows users (mostly teachers and learners) to view, share, discuss, control, track online learning activities, records, etc. An Intelligent Learning Management System (ILMS) is a (reactive) mechanism adaptive to design. And proactive LMS, which delivers content to the current user based on their knowledge, expertise and learning style. Meanwhile, ILMS will support features and tools such as scheduling, routing, usability, reporting and

generating knowledge (i.e. auto poetics) in order to have the best learning- and learning- for the learner. Although these features and tools allow the LMS to function more intelligently, it must give its users the freedom to keep their own learning under control and turn off the intelligence to allow full access to all materials. The program must ensure that these features prevent the program from being poor in usability and a significant time consumption in teaching [2].
E-learning systems have, over time, adapted to the learning needs and processes. Most learning programs also have student profiles and models that assess a learner's personality can determine the average rate of an individual's ability level and use the correct learning pedagogy to improve the learning process. The key objective of any educational learning system is to ensure that the student's learning has improved in line with their performance. Mainly, this is achievable through the integration of different tools and methodologies that assist in understanding the learner's knowledge level and create a conducive learning environment. Different approaches are used in e-learning systems, including face-to-face classes, online education, and training, which are mainly live videos that take place in real time. Certain approaches which are either pre-recorded or available upon request include group collaboration, multimedia, web-based learning, and support for results [3].

This paper is split in to six sections. The first section is introduction. The second section is explained the literature review. The third section is methodology. The fourth section is the result of the study. The section five is discussion. Six, conclusion and future work

\section{LITERATRE REVIEW}

This section discusses the artificial intelligent to illustrate the need for this SLR.

\subsection{Artificial Intelligent Overview}

Artificial intelligence has been consistently developing through the innovative technological changes that have been taking place globally. It is known as intelligent behavior by machinery instead of natural human intelligence (NI) [4].

The main goal of Artificial Intelligence (AI) is to research how artificial systems can be built that perform tasks usually done by humans. AI is a very significant discipline, which includes a range of a well-recognized which advanced areas: Expert Programs, Fuzzy Logic, Genetic Analytics, Language Analysis, and Logic Programming [5].

\subsection{Artificial Intelligent Approaches}

There are several AI approaches, such as Fuzzy Logic (FL), Decision Tree, Bayesian systems, Neural Networks, Genetic Algorithms, and Hidden Markov Systems, used in adaptive education systems. There are different ways of using AI approaches in adaptive education systems. The central aim of some programs is to analyses and evaluate student characteristics in order to create student profiles with the goal of determining their overall phase of knowledge to be extracted as a foundation for recommended software teaching. These AI strategies are useful in this regard for many purposes, including being able to improve and mimic the human life choice-making process and to create automated and reliable training-learning models automated and reliable training-learning models [3]. 


\section{1- Decision Tree}

It is a tree where each node reflects an option between a different number of options, and each branch node represents a decision. Decision tree is widely used to gather knowledge for decision making purposes. The decision tree begins with such a root node that lets users take action [3].

\section{2- Neural networks}

It is increasingly used to model human actions, and therefore reproduce human interactions and reactions. It basically consists of a large number of interlinked neurons or individual components that work together to retain information and resolve issues [3]

\section{3- Data mining}

It turned as the current trend in the IT field. Data mining is also necessary to implement in e-learning system to improve the system [6].

\section{4- Bayesian networks}

A commonly used approach for the simulation of students in intelligent education systems. A Bayesian Network (BN) is a Clear A cyclic Network (DAG), that is, a graph showing and explaining the spread of likelihood in such a way as to allow a proficient distribution of probability as well as an accurate depiction [3].

5- Hidden Markov Model

It is a set of unknowable states that follow the rules of the Markov property in a circumstance where the interconnections between true observation and unobserved state emerges from a distribution of probabilities [3].

\subsection{Artificial Intelligent Applications in LMS}

The use of artificial intelligence plays a major role in enabling diagnostic processes in different devices. In this scenario, we are looking at the use of $\mathrm{AI}$ in setting up an online learning program. E-learning is defined as the application of computers and web-based technologies to deliver various solutions designed to promote the development of education. It has emerged as a key tool for educational institutions to teach and learn. Many of its uses include preparation, upgrading, and employee skills creation, classroom learning for students and professional development. The benefit of E-Learning is that it is not only limited to formal education but also to other training courses and forms of training pieces. Learning System. According to Allen and Seaman, most of the learners 'post-secondary education and graduate level in learning institutions located in the United States of America primarily delivered their courses online in the year 2008. This figure increased to eighty-one per cent by 2014. More than 77 per cent of U.S. - based businesses already deliver online training solutions [4]

E-learning systems have been used for a variety of purposes, including technical, corporate, and educational advancement. In the educational system, e-learning programs also rely on the use of analysis to analyses a student's actions as compared to the use to didactic content and procedures used to assess standard education levels. Each course has its own life cycle, which includes the preliminary phase, intermediate, and final phase. Those three steps decide the creation of content for an E-learning program. Some main processes and sub-processes have to do with any e-learning framework, including mining relationships, clustering, prediction, human judgment / exploratory data analysis, and model-based discovery. The instructor is on one end of the network and the teacher and students on the other end. Meanwhile, there is the learning management system that conducts two processes that are evaluating and storing data requested on one end by teachers and students and on the other end data is analyzed to test the use and storage of information. In conclusion, AI has a wide variety of applications that have made learning more flexible and better results for students [7].

We define an intelligent component of an e-learning network that enhances its local ontology with new ideas and relationships gained by querying a remote base of information. The designed Smart Module's main strengths are autonomy and intelligence. The developed smart component should be able to increase the effectiveness of the educational benefits it offers and allow new services when incorporated into an existing learning management system to be provided to its users as a result of the introduction of these technologies. Future work will concentrate on improving the enrichment cycle in ontology, and creating objective indicators for measuring a system's enhanced knowledge [8].

LMS use is becoming more and more abused. This paper proposes an IT 'S combined with LMS which uses Moodle as a case study, taking into consideration the student's access and outcomes to the trainer's suggested activities. More advanced assignments are accessible to students with better performance, allowing for more successful learning, improving their abilities and maintaining a fair level of learning. Learners are categorized by the ratings they have earned, and their participation in the different services. An adaptive environment that continually updates its profile may transform a student with a simple profile to an average profile. These profile changes can be observed in an extension of this model and showed to the teacher [9].

\subsection{Learning Management System Overview}

LMS has developed rapidly in terms of instructional content, technical capabilities, and methods of interaction that are incorporated into an LMS application. In educational institution which includes Blackboard, Moodle, dotLRN. The benefit gained in this cost factor is this form of technology that can help you achieve learning and teaching without charging any fees for the certificate. The existence of a number of LMS on the market makes it difficult for educational institutions to select them. It's all about making an option that will fulfill the requirements in part or even everything [10].

\subsection{Essential Factors of LMS Applications}

The following study examines the influence of learning styles by integrating tailored training courses that fit the characteristics of the learner within the LMS. The results showed that the learners had different preferences in the LMS environment based on different learning styles. This article focuses on keeping the personality traits of the learner in mind by incorporating adaptability into the learning model. Based on that approach, the latest Moodle based LMS has been applied. This will allow the expansion of LMS to support teachers and learners. The study results are important to ensure that the courses have the functionality that suits various learning types [10].

In addition to the crucial factors, LMS analysis had conducted using various motivational factors modules that make learners successful. A prototype was built to find which module would be ideal for learner motivation. The research was performed online, and the prototype was built on the basis of one that fit everyone. This research explores the motivational factors in 
the use of LMS by students and uses a test to assess e-learning programs which have a beneficial effect on the desire to learn. To this end, an e-learning structure with various e-learning modules focused on an LMS has been investigated, and the degree to which the individual components have an effect on learning encouragement. Results of analysis show the elearning [11].

A survey is conducted among a few numbers of learners to find the crucial factors of LMS affecting them based on the quality of service, technical, system, and information. For determining the ease and usefulness to students, considered by a well-designed and user-friendly interface. Study results that the students accept the LMS, which meets their expectations on the mentioned vital factors. This study reveals that these essential variables are crucial indicators of the approval and happiness of the students, which directly affect their choice to use LMS. The most important decisive factor impacting the reception and satisfaction of the students was program consistency. Therefore, a higher education institution must weigh all these important considerations before adopting an integrated learning atmosphere with LMS for the success and approval of the students [12].

\subsection{Learning Management System Issues}

Some of e-learning's main issues are how to select an LMS that would be the most effective and satisfy the needs. It will be more difficult to measure LMSs manually, more timeconsuming and more work required. A computer-aided program developed by the author that can be used to select the best LMSs. The software is developed and configured using MS-Visual Studio. NET. Some of e-learning's main issues are how to select an LMS that would be the most effective and satisfy the needs. It will be more difficult to measure LMSs manually, more time-consuming and more work required. A computer-aided program developed by the author that can be used to select the best LMSs. The software is developed and configured using MS-Visual Studio. NET [13].

Learning Analytics is an advanced e-learning area. LA uses a variety approaches such as analyzing visual data, analyzing networking, forecasting, clustering, analyzing human review etc. And this will result in the instructor as well as the learners improving. But the research method has several problems in machine learning, collection, and assessment, questions of ethical privacy. The benefits include personalized course offerings, instructional development, student learning outcomes, action and process, customized instruction, enhanced teacher efficiency, post-educational career opportunities, and enhanced research in education. Difficulties include problems related to data collection, processing, assessment, assessment; failure to communicate with educational sciences; changing work environments; and ethics and privacy concerns. Such a thorough analysis offers an integrative update on LA systems, opportunities, and obstacles for instructors, course planners, and administrators so they can more effectively use LA to improve teaching and learning experience in university education [14].

This paper explores the value of electronic reviews for the ease of teacher feedback including monitoring, assessment, and declaration of results, as well as other learning software resources. Studies performed on the basis of the author's experience as administrators and instructors of Turku Applied Sciences University, where e-exams have been in use since 2012. Among the different software tools examined, VILLE has numerous features and considered suitable for both eexams and as an LMS. Further studies suggest the creation of a program that solves the current system's issues and can also carry out automated evaluation [15].

Modern LMS is intended to operate in a closed setting, particularly for a course or organization in question. This paper explores the growth of online systems and the incorporation of LMS into cloud-based systems, their issues and their futures. This research explains why many of today's most-used LMS worldwide cannot properly fit into modern cloud environments. The critical feature overview of the most widely applied LMS with suggestions for improvement and future growth had been identified [16].

One of the common higher education issues is evaluating the success of students in a course. The most commonly used instrument for measuring the success of the student in a course is by surveying the responses of the students about the course and its teacher via a questionnaire. With course assessment questionnaires in higher education institutions, various dimensions of course and efficacy of the teacher are measured and these results can be used to enhance measuring instruments [17].

\subsection{LMS Models Using Artificial Intelligent}

All 34 students who are using Edmodo Learning Management System, two User eXperience (UX) assessment techniques had been completed. The techniques employed are the UEQ and IEAM. Some students face difficulties, and then the Edmodo's results show favorable. Participants spoke about the problems they faced during the evaluation mission. Suggestions from participants include providing fields for remarks \& suggestions, answering submitted questions based on the features of LMSs, defining features of LMSs, and fast way of evaluation. The assessment results in Edmodo's progress and improved evaluation methods to be developed. This paper offers a summary of two UX evaluation approaches applicable to the Edmodo Learning Control system. To assess Edmodo's UX and the expectations of the approaches, we conducted a survey with 34 students. Findings showed that Edmodo generated outstanding UX. Nonetheless, approximately $41 \%$ of students indicated that they were unable to completely evaluate their UX using the techniques, indicating a need for progress [18].

Web, Database, and Video servers needed to create an elearning platform. The development of this framework looks for security issues, network attacks, etc. The author developed a suitable LMS system, and tested its performance for three years. Mitigation of the problems faced during the test period and adequate evaluation of its operation. The most important contribution of this study was that the architecture of the new LMS had changed to provide a more efficient performance than the current LMSs by solving the issue of traffic congestion often seen in video services. This were done using a small number of servers and balancing the loads. The design used by the project can also be extended to most web servers as it supports applications based on Android, Java, and HTML. As a cloud-based LMS, this system tested its efficacy and reliability over a three-year period during which the findings were reasonable [19].

Universities and students shift to the systems of e-learning. Since the content provided to all learners is the same and the same learning style is applied for all, the authors apply userconscious adaptive learning to LMS, which enables the platform to provide sufficient learner information. The author suggested a new intelligent interactive training model be used 
in LMS to address this problem of variance in learning rates and the difficulty of the course, which is taught by LMS. This lets the designer identify the student's academic style and encourages the required learning opportunities for the learner. This management network would be effective and safe for diverse LMS learners [20].

This paper suggests a nonlinear transition to multi-carrier equalization in the Orthogonal Frequency Multiplexing Division (OFDM), with variable step length. We review the Fixed LMS (FLMS), VLMS performance and our suggested algorithm. This step-size variable LMS (VLMS) algorithm enhances OFDM's performance, particularly at low SNRs, without increasingly complex [21].

The need for online education that incorporates student features, evolving social needs and preferences along with the internet network could turn the LMS into a better tool that operates in a more personalized manner. For typical LMS however, the possibilities for customization are limited. Customization of e-learning is historically related to ITS. Methods have been developed particularly in Artificial Intelligence (AI) practices to personalize LMS. The first effort to personalize in LMS was introduced with the standardization of the SCORM [22].

Learning Management System (LMS) is used in classroom online learning and teaching, with teachers and students supporting learning services. The purpose of this work is to propose a framework for incorporating an Intelligent Tutoring Program (ITS) into LMS. In this study students are classified by their performances, taking into account the grades received and their participation in the various materials included in the course. With this divergence, an integrated system can be created, based on a traditional LMS, which continually updates the student's profile and helps each lead the teaching and learning process. Smart tutors that provide a much more flexible environment, integrating more complex instructional methods, but are usually designed ad hoc for particular areas and with reusability problems [23].

We've seen a revolution in the education sector in the past few years. The first paradigm focuses on the direct encounters between an instructor and a student due to repetitive process automation, which is followed by the second paradigm based on applying LMS. This model has been modified by an AI system reproducing intelligence procedures for the instructor and the student. In the proposed approach the interaction between the teacher and the student is carried out in the online environment in the correspondence of the AI agent. This operates according to the details the LMS services have provided. This AI agent is likely to demonstrate competences in a specific field in conjunction with the general communication and intelligence skills [24].

The research provides a method of building and adapting a tutoring model by using both artificial neural networks and deep learning. The basic principle is that the tutoring rules can be learned first by observing human tutors 'behavior, and then modified at runtime. By observing how each learner is responding within the learning context in various learning process states. The Proximal Development Zone has been adopted as the underlying principle for evaluating the learning experience's effectiveness and performance [25].

\section{RESEARCH METHODOLOGY}

This section discusses the methodologies and intent of writing an SLR paper on the LMS domain's current models using AI technology. Secondly, it offers researchers help to find out the issue of LMS models.

\subsection{Research Motivation}

The research questions based on the motivation as in Table 1 .

Table 1. Questions of the research.

\begin{tabular}{|c|c|}
\hline Research Question & Motivation \\
\hline $\begin{array}{c}\text { How much activity was } \\
\text { carried out recently? }\end{array}$ & $\begin{array}{c}\text { Plan to deal with the activity } \\
\text { was carried out recently 2018- } \\
2020\end{array}$ \\
\hline $\begin{array}{c}\text { What are issues related } \\
\text { to the area? }\end{array}$ & $\begin{array}{c}\text { Plan to deal with the issues } \\
\text { faced by LMS }\end{array}$ \\
\hline $\begin{array}{c}\text { What are the different } \\
\text { LMS models used AI } \\
\text { methodology that were } \\
\text { used to solve the issues? }\end{array}$ & $\begin{array}{c}\text { The goal is to look for AI } \\
\text { functionality which will help } \\
\text { overcome LMS issues. }\end{array}$ \\
\hline
\end{tabular}

\subsection{Search Strategy}

Throughout this phase, we have built search approach to obtain all the related studies that respond to the research questions. This approach described which references to search and how the search terms should be used should be executed. The selection process meets the suggested guidelines (Kitchenham \& Charters, 2007). [26]

The search query included the keywords "learning management system (LMS)," "Artificial Intelligent", "Model "and" issue ". Table 2 demonstrates the conveyance of tests for each database.

Table 2: Result per database

\begin{tabular}{|c|c|c|c|}
\hline $\begin{array}{c}\text { Electronic } \\
\text { database }\end{array}$ & IEEE & $\begin{array}{c}\text { Science } \\
\text { direct }\end{array}$ & Springer \\
\hline Result & $31 \%$ & $29 \%$ & $40 \%$ \\
\hline
\end{tabular}

Total number of included publications per database

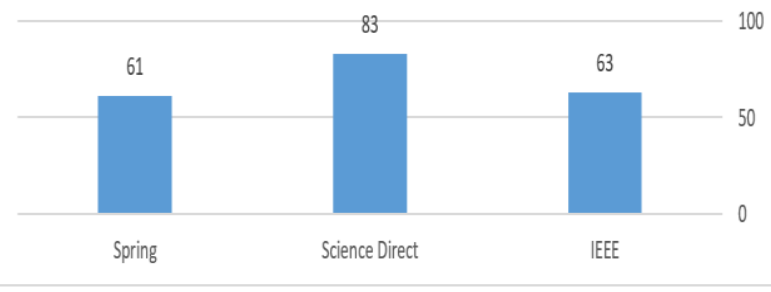

Fig 1: Percentage of results per database

\subsection{Inclusion and Exclusion Criteria}

We chose 207 different articles in inclusion which were close to our keyword for research. After reviewing the abstract and the conclusion, we exclude the irrelevant papers, we consider to be very important to our interests (see table 3 ).

Table 3. Criteria for Inclusion and Exclusion.

\begin{tabular}{|c|c|}
\hline Inclusion Criteria & Exclusion Criteria \\
\hline $\begin{array}{c}\text { Include the article's latest } \\
\text { edition, if various versions }\end{array}$ & $\begin{array}{c}\text { Remove articles for the non- } \\
\text { journal and non-conferences. }\end{array}$ \\
\hline
\end{tabular}




\begin{tabular}{|c|c|}
\hline are accessible. & \\
\hline $\begin{array}{c}\text { Include the published } \\
\text { papers from (Jan-2018 and } \\
\text { 2020). }\end{array}$ & $\begin{array}{c}\text { Remove Papers, Chapters of } \\
\text { Articles, and Thesis. }\end{array}$ \\
\hline $\begin{array}{c}\text { Feature documents in } \\
\text { electronic format, written } \\
\text { in English. }\end{array}$ & $\begin{array}{c}\text { Not relevant to study } \\
\text { Questions. }\end{array}$ \\
\hline
\end{tabular}

\subsection{Selection the Study}

This phase is intended to choose narratively applicable research that could answer the key paper questions. We're clarifying a set of inclusion and exclusion requirements (see table 3).

Table 4. Selected papers

\begin{tabular}{|c|c|c|}
\hline Title & Year & Ref \\
\hline $\begin{array}{c}\text { Smart Education with artificial } \\
\text { intelligence based determination of } \\
\text { learning styles }\end{array}$ & 2018 & [27] \\
\hline $\begin{array}{l}\text { Towards Emotionally Aware AI Smart } \\
\text { Classroom: Current Issues and Directions } \\
\text { for Engineering and Education }\end{array}$ & 2018 & [28] \\
\hline $\begin{array}{c}\text { Analysis of student behavior in learning } \\
\text { management systems through a Big Data } \\
\text { framework }\end{array}$ & 2019 & [29] \\
\hline $\begin{array}{l}\text { SMART Education Framework for } \\
\text { Adaptation Content Presentation }\end{array}$ & 2018 & [30] \\
\hline $\begin{array}{c}\text { Design of a mobile-based learning } \\
\text { management system for incorporating } \\
\text { employment demands: Case context of an } \\
\text { Australian University }\end{array}$ & 2019 & [31] \\
\hline $\begin{array}{l}\text { Education } 4.0 \text { - Artificial Intelligence } \\
\text { assisted Higher Education: Early } \\
\text { recognition System with Machine } \\
\text { Learning to support Students' Success }\end{array}$ & 2018 & [32] \\
\hline $\begin{array}{l}\text { Artificial Intelligence Powered MOOCs: } \\
\text { A Brief Survey }\end{array}$ & 2018 & [33] \\
\hline $\begin{array}{l}\text { Data-informed design parameters for } \\
\text { adaptive collaborative scripting in across- } \\
\text { spaces learning situations }\end{array}$ & 2019 & [34] \\
\hline $\begin{array}{l}\text { A study on the LMS platform } \\
\text { performance and performance } \\
\text { improvement of K-MOOCSs platform } \\
\text { from learner's prospect }\end{array}$ & 2018 & [35] \\
\hline $\begin{array}{c}\text { Enhancing LMS Experience through } \\
\text { AIML Base and Retrieval Base Chabot } \\
\text { using R Language }\end{array}$ & 2019 & [36] \\
\hline $\begin{array}{l}\text { Artificial intelligence as a support } \\
\text { technique for university learning }\end{array}$ & 2019 & [37] \\
\hline
\end{tabular}

\subsection{Data Extraction}

The purpose of this phase is to address the paper questions by gathering the data needed. We collected the data set out in Table 4 from each analysis.
Table 5. Data extraction form selected papers

\begin{tabular}{|c|c|c|c|}
\hline Idea & Method & Result & $\begin{array}{c}\text { Limitation } \\
\text { or Future } \\
\text { work }\end{array}$ \\
\hline $\begin{array}{c}\text { Suggesting } \\
\text { a program } \\
\text { that } \\
\text { make into } \\
\text { consideratio } \\
\mathrm{n} \text { different } \\
\text { educational } \\
\text { styles and } \\
\text { artificial } \\
\text { intelligence } \\
\text { methods to } \\
\text { test teaching } \\
\text { and learning } \\
\text { styles. } \\
\text { [27] }\end{array}$ & $\begin{array}{l}\text { Theory of } \\
\text { education } \\
\text { and the } \\
\text { process of } \\
\text { artificial } \\
\text { intelligence }\end{array}$ & $\begin{array}{l}\text { Provides a } \\
\text { list of } \\
\text { various } \\
\text { students } \\
\text { learning } \\
\text { attributes } \\
\text { that can be } \\
\text { monitored } \\
\text { on the basis } \\
\text { of which } \\
\text { customized } \\
\text { learning can } \\
\text { be } \\
\text { delivered. } \\
\text { Enables the } \\
\text { reference } \\
\text { implementat } \\
\text { ion to } \\
\text { narrow } \\
\text { down } \\
\text { possible } \\
\text { learning } \\
\text { methodolog } \\
\text { y models } \\
\text { that can be } \\
\text { used to } \\
\text { teach active } \\
\text { learning. }\end{array}$ & ----- \\
\hline $\begin{array}{l}\text { Proposing } \\
\text { an } \\
\text { intelligent } \\
\text { class that } \\
\text { could } \\
\text { enhance } \\
\text { speaker } \\
\text { presentation } \\
\text { consistency } \\
\text { and } \\
\text { memorabilit } \\
\text { y. [28] }\end{array}$ & $\begin{array}{c}\text { Deep } \\
\text { learning, } \\
\text { GPU } \\
\text { computation } \\
\text {, adaptive } \\
\text { processing, } \\
\text { and } \\
\text { emotional } \\
\text { recognition }\end{array}$ & $\begin{array}{c}\text { The } \\
\text { software } \\
\text { collected } \\
\text { scores from } \\
\text { participants } \\
\text { to assess a } \\
\text { presentation' } \\
\text { s accuracy, } \\
\text { and } \\
\text { recommend } \\
\text { ed practical } \\
\text { and } \\
\text { educational } \\
\text { assessment } \\
\text { measures to } \\
\text { measure the } \\
\text { efficacy and } \\
\text { viability of } \\
\text { the } \\
\text { presentation }\end{array}$ & $\begin{array}{l}\text { This project } \\
\text { provides } \\
\text { broad } \\
\text { applicability } \\
\text { in fields } \\
\text { such as } \\
\text { Relationship } \\
\text { s between } \\
\text { patient and } \\
\text { doctor in } \\
\text { medicine or } \\
\text { any teaching } \\
\text { circumstanc } \\
\text { e in which } \\
\text { people } \\
\text { communicat } \\
\text { e. }\end{array}$ \\
\hline $\begin{array}{c}\text { Analyzing } \\
\text { the area of } \\
\text { education } \\
\text { seen as a } \\
\text { smart } \\
\text { learning } \\
\text { setting. } \\
\text { [29]. }\end{array}$ & $\begin{array}{c}\text { Strategies of } \\
\text { statistical } \\
\text { law and } \\
\text { association } \\
\text { procedure }\end{array}$ & $\begin{array}{l}\text { Provided a } \\
\text { roadmap to } \\
\text { smart } \\
\text { educational } \\
\text { communitie } \\
\mathrm{s} \text { for } \\
\text { combining } \\
\text { formal and } \\
\text { informal } \\
\text { education to } \\
\text { form }\end{array}$ & $\begin{array}{l}\text { To research } \\
\text { the action } \\
\text { patterns of } \\
\text { lecturers as } \\
\text { well. It can } \\
\text { also be used } \\
\text { to classify } \\
\text { positive } \\
\text { driver habits } \\
\text { in other } \\
\text { areas, such }\end{array}$ \\
\hline
\end{tabular}




\begin{tabular}{|c|c|c|c|}
\hline & & $\begin{array}{l}\text { student's } \\
\text { adaptation } \\
\text { profile }\end{array}$ & $\begin{array}{l}\text { as smart } \\
\text { cards, or } \\
\text { smart homes } \\
\text { to monitor } \\
\text { residents } \\
\text { 'energy } \\
\text { usage. }\end{array}$ \\
\hline $\begin{array}{c}\text { Suggesting } \\
\text { a new } \\
\text { method for } \\
\text { adapting } \\
\text { material } \\
\text { delivery to } \\
\text { learner } \\
\text { needs and } \\
\text { learner } \\
\text { physical } \\
\text { impairment. } \\
{[30] .}\end{array}$ & $\begin{array}{l}\text { Multimedia } \\
\text { integration }\end{array}$ & $\begin{array}{l}\text { Using the } \\
\text { four } \\
\text { Engines: } \\
\text { Student } \\
\text { Detection } \\
\text { Engine), } \\
\text { Student } \\
\text { Model } \\
\text { System Tran } \\
\text { s } \\
\text { coding Engi } \\
\text { ne and } \\
\text { Adjustment } \\
\text { Presentation } \\
\text { Engine, } \\
\text { Method for } \\
\text { Dynamic } \\
\text { Integrated } \\
\text { Hypermedia } \\
\text { System }\end{array}$ & $\begin{array}{c}\text { The } \\
\text { proposed } \\
\text { system will } \\
\text { be reviewed } \\
\text { and assessed } \\
\text { and we will } \\
\text { research and } \\
\text { use media } \\
\text { transcoding } \\
\text { for sign } \\
\text { language in } \\
\text { order to } \\
\text { enhance the } \\
\text { delivery of } \\
\text { information } \\
\text { to deaf } \\
\text { learners. }\end{array}$ \\
\hline $\begin{array}{c}\text { This } \\
\text { research } \\
\text { explores and } \\
\text { tests an } \\
\text { emerging } \\
\text { mobile- } \\
\text { based } \\
\text { platform for } \\
\text { the } \\
\text { developmen } \\
\text { t of existing } \\
\text { LMS } \\
\text { approaches. } \\
\text { [31]. }\end{array}$ & $\begin{array}{c}\text { Technology } \\
\text { process } \\
\text { concept }\end{array}$ & $\begin{array}{l}\text { The built } \\
\text { artefact is } \\
\text { expected to } \\
\text { be } \\
\text { accessible } \\
\text { across } \\
\text { Australian } \\
\text { higher } \\
\text { education } \\
\text { segments to } \\
\text { enhance } \\
\text { industry } \\
\text { take-up to } \\
\text { enhance } \\
\text { learning } \\
\text { pedagogy. }\end{array}$ & -- \\
\hline $\begin{array}{l}\text { Develop an } \\
\text { innovative } \\
\text { approach to } \\
\text { advancing } \\
\text { AI in } \\
\text { Education } \\
\text { 4.0. - }\end{array}$ & $\begin{array}{l}\text { Prediction - } \\
\text { Accounting } \\
\text { method }\end{array}$ & $\begin{array}{l}\text { 1- Estimate } \\
\text { the final } \\
\text { score for the } \\
\text { students } \\
\text { before } \\
\text { taking part } \\
\text { in the final } \\
\text { exam. } \\
\text { 2- Raise the } \\
\text { rate of } \\
\text { failure of } \\
\text { the exams } \\
\text { by almost } \\
\text { half. }\end{array}$ & $\begin{array}{l}\text { We should } \\
\text { consider } \\
\text { more } \\
\text { variables } \\
\text { derived } \\
\text { from the } \\
\text { student } \\
\text { experience } \\
\text { to tackle } \\
\text { explanatory } \\
\text { and live } \\
\text { information } \\
\text { for future } \\
\text { study, such } \\
\text { as biological } \\
\text { signals }\end{array}$ \\
\hline $\begin{array}{l}\text { Develop } \\
\text { student } \\
\text { education } \\
\text { attitude, } \\
\text { increase }\end{array}$ & $\begin{array}{l}\text { The state of } \\
\text { the art AI } \\
\text { work } \\
\text { applied to } \\
\text { MOOCs has }\end{array}$ & $\begin{array}{l}\text { Highlightin } \\
\text { g how AI } \\
\text { methods and } \\
\text { techniques } \\
\text { can enhance }\end{array}$ & -- \\
\hline
\end{tabular}

\begin{tabular}{|c|c|c|c|}
\hline $\begin{array}{c}\text { student } \\
\text { participation } \\
\text { and enhance } \\
\text { learning } \\
\text { outcomes. } \\
\text { [35]. }\end{array}$ & $\begin{array}{c}\text { been } \\
\text { reviewed. }\end{array}$ & $\begin{array}{c}\text { simulation } \\
\text { of learners, } \\
\text { learning } \\
\text { experiences } \\
\text { and } \\
\text { evaluation } \\
\text { of learners. } \\
\text { We } \\
\text { demonstrate } \\
\text { d how AI } \\
\text { can be } \\
\text { incorporated } \\
\text { seamlessly } \\
\text { into } \\
\text { virtually } \\
\text { every part } \\
\text { of the } \\
\text { MOOC } \\
\text { ecosystem. }\end{array}$ & \\
\hline $\begin{array}{l}\text { An effort to } \\
\text { predict the } \\
\text { potential } \\
\text { involvement } \\
\text { of } \\
\text { individual } \\
\text { users in } \\
\text { collaborativ } \\
\text { e education } \\
\text { activities in } \\
\text { a predictive } \\
\text { analysis } \\
\text { pyramid- } \\
\text { based } \\
\text { collaborativ } \\
\text { e learning } \\
\text { activity }\end{array}$ & $\begin{array}{c}\text { Predictive } \\
\text { analytics }\end{array}$ & $\begin{array}{l}\text { Obtain an } \\
\text { approximati } \\
\text { on of the } \\
\text { actual } \\
\text { participation } \\
\text { of } \\
\text { participants } \\
\text { in } \\
\text { cooperative } \\
\text { education } \\
\text { practices } \\
\text { based on } \\
\text { data } \\
\text { obtained } \\
\text { from } \\
\text { different } \\
\text { learning } \\
\text { spaces that } \\
\text { reflected } \\
\text { their } \\
\text { individual } \\
\text { and } \\
\text { cooperative } \\
\text { learning } \\
\text { behaviors in } \\
\text { recent } \\
\text { practices. }\end{array}$ & $\begin{array}{l}\text { The use of } \\
\text { learning } \\
\text { data sets } \\
\text { constituting } \\
\text { a small } \\
\text { number of } \\
\text { samples } \\
\text { which are } \\
\text { also } \\
\text { unbalanced } \\
\text { in the target } \\
\text { class. }\end{array}$ \\
\hline $\begin{array}{l}\text { Recommend } \\
\text { s an } \\
\text { education } \\
\text { managemen } \\
\text { t framework } \\
\text { based on } \\
\text { current } \\
\text { LMS } \\
\text { characteristi } \\
\text { cs and } \\
\text { supports the } \\
\text { different } \\
\text { programs in } \\
\text { an } \\
\text { integrated } \\
\text { manner; }\end{array}$ & $\begin{array}{c}\text { Smart } \\
\text { material on } \\
\text { studying. }\end{array}$ & $\begin{array}{c}\text { The findings } \\
\text { showed that } \\
\text { most K- } \\
\text { MOOCS } \\
\text { had largely } \\
\text { surpassed } \\
\text { the norm }\end{array}$ & $\begin{array}{l}\text { Nonetheless } \\
\text {, in the } \\
\text { future it will } \\
\text { become a } \\
\text { culture } \\
\text { which will } \\
\text { encourage } \\
\text { Making } \\
\text { education } \\
\text { more } \\
\text { effective by } \\
\text { learning } \\
\text { using online } \\
\text { resources } \\
\text { like home } \\
\text { education. }\end{array}$ \\
\hline $\begin{array}{c}\text { Presents a } \\
\text { chatbot } \\
\text { model in }\end{array}$ & $\begin{array}{l}\text { AIML } \\
\text { and rule- }\end{array}$ & $\begin{array}{c}\text { This chatbot } \\
\text { will also } \\
\text { generate }\end{array}$ & $\begin{array}{c}\text { This } \\
\text { program can } \\
\text { be extended }\end{array}$ \\
\hline
\end{tabular}




\begin{tabular}{|c|c|c|c|}
\hline $\begin{array}{l}\text { LMS that } \\
\text { will solve a } \\
\text { student's } \\
\text { several ad- } \\
\text { hoc queries } \\
\text { and can be a } \\
\text { very useful } \\
\text { tool }\end{array}$ & $\begin{array}{l}\text { based } \\
\text { system }\end{array}$ & $\begin{array}{c}\text { dozens of } \\
\text { query-based } \\
\text { knowledge } \\
\text { to help the } \\
\text { organization } \\
\text { understand } \\
\text { its } \\
\text { requirement } \\
\text { s. }\end{array}$ & $\begin{array}{l}\text { by more } \\
\text { thorough } \\
\text { specificatio } \\
\mathrm{n} \text { of more } \\
\text { ad-hoc } \\
\text { distinct user } \\
\text { requests, } \\
\text { whereas the } \\
\text { institution } \\
\text { may assist } \\
\text { or reply to } \\
\text { each user in } \\
\text { a more } \\
\text { customized } \\
\text { way. }\end{array}$ \\
\hline $\begin{array}{l}\text { Suggests the } \\
\text { introduction } \\
\text { of an expert } \\
\text { system that } \\
\text { communicat } \\
\text { es with } \\
\text { students and } \\
\text { assesses } \\
\text { their } \\
\text { responses to } \\
\text { analytics } \\
\text { data systems } \\
\text {. [34] }\end{array}$ & $\begin{array}{l}\text { Expert } \\
\text { System }\end{array}$ & $\begin{array}{l}\text { Log in and } \\
\text { suggest } \\
\text { activities } \\
\text { that match } \\
\text { with each } \\
\text { student's } \\
\text { requirement } \\
\text { s. }\end{array}$ & --- \\
\hline
\end{tabular}

\subsection{Analyzing the Data}

This is described as follows:

a. The repositories and how much number of query output.

b. The number of significant scenarios published per year.

c. The graph showing the publish papers in conferences or journal produced from the last results

d. A comprehensive filtering phase that takes place on choosing databases.

\subsection{Publication Trend}

Trend in publishing we mentioned papers in our research that were no older than 2018. We tried to highlight certain high impact factor papers or quotes, so most paper choices were made based on quality publishers such as IEEE, Science Direct and Springer.

\section{RESULT}

This section describes the actual results obtained from our paper research. They are subdivided into three sections. In part 1 the activity carried out recently. In second part work on the issues of existing LMS Models. Finally, different LMS models used AI methodology is discussed in the last part.

\section{RQ1: How much research was recently carried out?}

In Figure 2, we have graphically plotted a selection of similar publications per site, and in Figure 3 for each year. Figures 4, 5,6 indicate individual number of articles posted in each database from 2018 to 2020 .

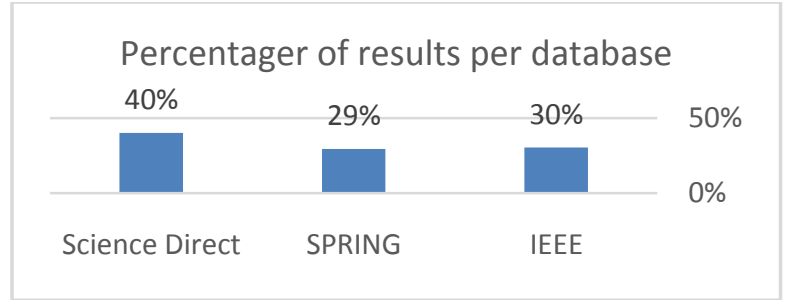

Fig 2: Total number of included publications per database

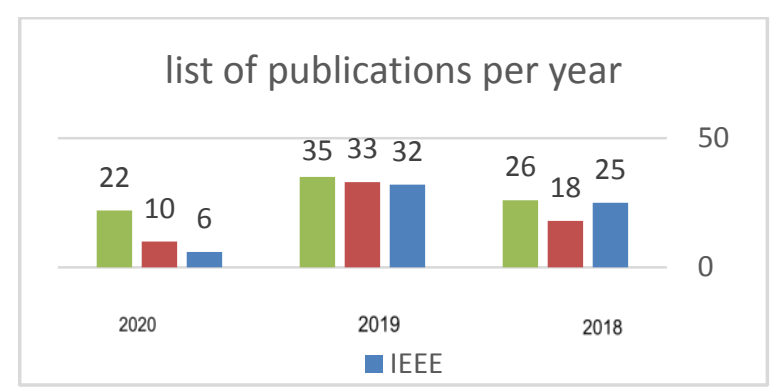

Fig 3: Range of publications every year

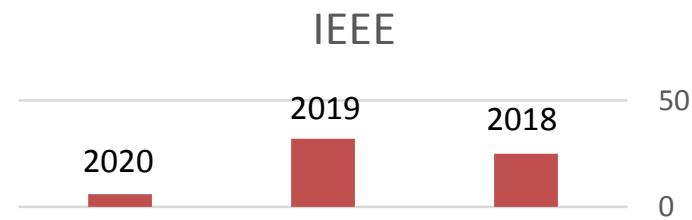

Fig 4: Range of IEEE publications every year

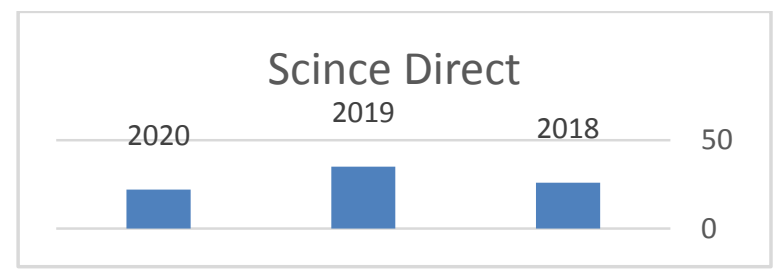

Fig 5: Range of Science Direct publications every year

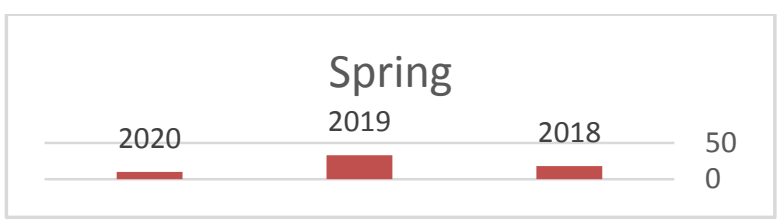

Fig: 6 Range of Springer publications every year

RQ2: What are issues related to the area?

Current learning systems lack adaptability; because they provide the same services to all users regardless of their specific requirement and wishes. Learner study as shown by their preferred pattern and a key move in having eLearning or conventional interests is to decide those. Students learn according to their individual preferences and a key move in making learning or conventional education flexible is to evaluate these. Training models have been proposed to assess the training types [27]

While the state-of - the-art work identifies existing problems and offers potential directions for the implementation of the new program in engineering and education disciplines. The key issues lie in: 1) the incorporation of these developments into an all-inclusive program build; 2) their techniques 
integration to allow implementation in real-time; and 3) the measurement of relevant pedagogical factors for that can be used in algorithms [28]. There is a need for analytical tools to help analyze LMS data, and to provide new information to develop and even design new eLearning techniques and methodologies, according to several studies. It is also crucial to examine and choose the appropriate information from the LMS based on the objectives to be achieved before manipulating such information [29].

Students detect it hard to take lecture by providing a typical presentation that does not fulfill their requirements and wishes, in particular students with visual and auditory disabilities [30].

In addition, systematic methods of learning management systems (LMS) are yet to be established for higher education institutions to assist students and academics in meeting industry requirements. Nonetheless, there is a need to focus on developing an LMS solution to tackle issues of jobs and industry participation so that educational users can have direct involvement and awareness [31].

TTE performs tasks artificial intelligence cannot disrupt. The vision of technicians who meet the expectations of Industry 4.0 is the so-called "Tall Thin Engineer," with skills and credentials such as technology and leadership. Given the scale and speed of technical advancements, there is an extremely high need for AI-based continuing education-the work [32].

In certain ways, all AI research in MOOC relies on data to function-the aim is not to create new theoretical advances in AI but rather to use AI techniques to solve a problem in MOOC [33].

The forecasting topic of interest was developed as a supervised machine learning issue and solved using excellently-known supervised machine learning techniques, i.e. SVMs and NNs [34].

To recommend ways to improve the performance, technical problems and QoS of the system, as well as to reduce its costs, with a view to improving it as an integrated system [35].

This paper introduces a chatbot framework in LMS that can answer a student's several ad-hoc inquiries which can be a very useful tool for saving student and university time [36].

Universities are striving to develop academic methods which come from a traditional model. Traditional ideas base learning on instructor experience as well as activity growth. Studies performed in the field of education find that not all practices produce awareness in the students. The lessons have to adjust to each student's needs in order to create an effective model that will lead to learning. The problems found in this investigation are found by the learning experts: learning difficulties, Student needs to provide solutions by customized activities are not assessed, lack of input from the student, disappointment in the audience, ignorance of the approach used by the teachers, low acceptance of the instructional model, there is no motivation to learn in the student, the learning process is not the most suitable [37].

\section{RQ3: What are the different LMS models used AI} methodology that were used to solve the issues?

The study argued that adaptively is a necessity in the current day learning system, whose aim is to modify the content and learning paths of learners. The adaptive system also assists in reducing confusion and mental overload problems to increase their learning ability. The scholars also dispute that the current learning system does not have adaptively because it provides the same learning resources to all students regardless of their personal needs or preferences. Thus, the authors believe that allowing learns to study based on their preferences forms an essential step in making an old learning system adaptive. They used artificial intelligence skills and several learning models. When the students combined the learning models and their learning styles, they performed better. The researchers, however, realized that there is no software device that is readily accessible to provide the flexibility to choose the most appropriate learning model [27].

The research outlines the operational and technological modules of future smart classrooms. The system sends automated real-time feedback to a student via an open educator model through a presentation to enhance emotional awareness of the learner, efficiency of the presentation, and their communication skills. The scholars proposed a system established on theories, developments, and experimental studies in the sector of engineering. This system employs state-of-art techniques, including multimodal sensing, deep learning, cognitive recognition, and high-level performance GPU computing. The system evaluates visual and audio information to excerpt the learner's hand gestures, intonation, and body language information. The researchers used training and presentation modes as the two effective modes. In the training mode, the system absorbs how the mass assesses multimodal data. In contrast, the received data is used at the time of presentation to generate a real-time response to the presenter via emoji or haptic gloves in the presentation mode. Despite the successful results, the system experiences some setbacks, including the label noise in the crowd score. Also, the scholars found the Google Glass response delivery devices to be quite disturbing [28].

The study analyzed learner's behavior patterns in the eLearning context. Their major objective was to build a framework established on technologies of big data to find patterns of behavior learning management system (LMS) learners. The scholars maintain that the LMS has contributed significantly to the improvement of higher education globally. The employed visual analytical technique to examine the data collected on a case study carried out on university students at Murcia. Similarly, they used a Big Data framework to perform statistical and association rule techniques, which sped up the statistical examination of data. The scholars collected a substantial amount of data from the study, which could provide both the learners and the lectures with essential information to use in their educational ventures. The major limitations faced by the authors included the use of a huge volume of data and the a variety formats used to present information [29].

Another study evaluates ways of improving the typical educational systems to enable the student with physical disabilities especially those faced with hearing and visual challenges adapt to the new era learning. To address this issue appropriately, the authors adapted strategic measures and algorithms, which would be to enhance the student's dependability and perceived quality. Based on the research, the scholars realized that a large group of learners confirmed that learning was more manageable when teaching methods are based on Adaptive Learning System. The authors, however, appreciated that the artificial intelligence must be continuously advanced to be more successful, which may be a bit costly in the long run [30].

A study conducted by Singh and Miah (2019) showed that mobile technologies had generated numerous opportunities for enhancing information delivery among people. The scholars' 
further claim that study on mobile uses for learning is yet at its developing phase and would help in creating individualbased education to improve their participation in learning and teaching purposes. Thus, the authors aim to create and evaluate an advanced mobile-based system to enhance the current technologies of the learning management system. This was achieved by linking an effective sector to the teaching and learning process in Australian college. The authors used the design science method to examine the solution artifact, which met the major demands of the investors. They projected that the created artifact would be used in Australian education segments to improve the pedagogy of education. However, the study proved to be a bit expensive because of the technologies employed [31].

In their research, Ciolacu et al. Explains that demand for adaptive and individualized learning is quite high in the current education system. Thus, they planned to use an innovative tactic to endorse artificial intelligence in the education system to forecast the final score of learners before sitting for their final checkup. Furthermore, they recommended recognition system fitted out with correct data obtained in a combined learning material with an individualized exam at the starting of the semester. The scholars used didactic techniques combined with education data analysis and Algorithms for machine learning. Using the study, the authors reduced the failure rate in the exam by almost half and provided the learners with a clear understanding. However, the major issue is to use of the data acquired for the fast detection Program [32].

We shift towards an early warning program that helps to identify at-risk students. Under this respect, we used the recognition system on many courses, and found many at-risk learners. In experiments they increased the rate of regression by nearly half. Further variables derived from the students background, such as biological signals, can be considered for future research in order to solve explanatory and live information [33].

The research determine how prognostic analytics could be employed to update the invention of adaptive joint educational sets. In their study, the scholars used both active (students in a classroom) and inactive (distance learners) participants and prediction done by the SVM and NNs classifiers. Similarly, the technique of Cohen's kappa was employed to determine the accuracy of the two classifiers. In the classroom context, the authors realized that there was no consensus between the incidences created by classifying software and data analyzed by the Cohen kappa method, unlike in the case of distance learning. The classifier's bad success caused noisy data. The use of an inadequate number of samples that were imbalanced in regards to the target group created a major setback in the study. The period between the data collection and time evaluation also limited the performance of the classifier [34].

In this study, the research acknowledged that eLearning has an essential effect on the education sector, including the higher learning institutes like the universities. However, the scholars dispute that the current eLearning system comprises of only a one-way teaching approach. Thus, their major objective was to compare the current eLearning system that is largely used in the HEI to recommend possible ways of improving the system's efficiency and reduce its cost with an aim converting it to a collaborative system. They researched on the performances of the LMS context and the K-MOOCS context for intelligent systems and practical context. The researchers employed the estimated standard technique to the late facility position of the K-MOOCS to evaluate the requirements of the regular services and acknowledge the existing position of the reference framework. Their results revealed that a majority of system exceeded to a great extent the level. However, the scholars agreed that K-MOOCS ought to shed light on its correlation with MOOCS a little more [35].

This paper explores a chatbot model and is simple to be applied with computer language R. Using the language of the Artificial Intelligence Mark-up, broad keywords can be presented as queries in addition. If this crash, it is presented as a check with the aid of SQL lite. If both malfunctions then the same is passed to the human interface. The chatbot can produce several query from data to assist the organization get to know the user in greater depth, and each user can be assisted or responded to in a very personalized manner [36].

The study proposed framework helps designers and tutors determine the best practices, given the scenario identified by the learner's characteristics and learning background. The proposed system determines the best instructional approaches and collects the greatest amount of data from the educational situation as inputs. With the data included, the system determines the pattern or combination of patterns that best fits the user's situation; The effect of using the system allows one to propose a range of activities that lead to successful learning, using the principle of multi criteria; it provides the outcome of the appropriate parameters of each activity based on the learners 'actions [37]

\section{DISCUSSION}

The research points to the need for LMS supported by Artificial Intelligence (AI) and, in general, the use of Artificial Intelligent that provide flexibility to educational settings according to user requirements and to allow for a higher degree of visuals between classroom environment and users.

The AI approaches would be used to enable the identification of learner needs bases based on factors affecting the academic output of learners. AI has become a component of computers which can be taken as action support, evaluation of student and learning material. AI and related e-learning technologies play an important role in delivering intelligence-based elearning systems and behavior-based in some instances. In order to integrate intelligence into learning management systems to improve the behavior of learners, different cultures, learning styles and different teaching styles are required. Techniques such as integrating intelligence. natural language processing will help LMS, where in-depth search strategies can be used to create content that illustrates a learner's actions. The learners will take advantage of the Virtual LMS to gain the required learning style material by model. Therefore, the leaners would be more involved in using the program. The following table 1 summarize the current state-of-the-art models dealing with LMS using AI.

The key objective of the study presented is to investigate the different learning management system (LMS) problems to explain how an intelligent learning environment with the Artificial Intelligence techniques can solves the problems. This paper explains the AI methods but the specifics of the design and how the models work is points as a future process.

\section{CONCLUSION AND FUTURE WORK}

Over the last few decades, Learning Management System have become the centre of publicity and enormously help educators deliver educational opportunities to students. Because artificial intelligence was used for instructional advice, developers of learning management systems showed a 
great deal of interest in making their products smarter and better. LMS is used as lecturer and students supporting methods in the education process in faraway education and classroom instruction. Teachers are able to provide students with content, do exercises and build tests. Nonetheless, for all students this process is performed in the same manner, regardless of their disparity in results and behavior. Using intelligent systems allows LMS to be automated as it provides the contact between an educator, a participant and an academic institution.

The number of education systems is increasingly growing and most institutions providing distant education use LMS to deliver their material online. This paper discussed different Learning Management Systems related AI. This paper explored a variety of emerging topics related to how the technologies of artificial intelligence are used in e-learning management system. The paper also discussed these methods and, as well as their importance in solving LMS problems. The main objectives of the presented paper is to investigate the different LMS problems and explains the variety of LMS models that used the Artificial Intelligent techniques for providing an intelligent learning environment and solving the problem. This paper is describing the AI techniques but the architecture details and how models works of such a system as future work.

\section{REFERENCES}

[1] O.Zawacki-Richter, V.I.Marín, M.Bond \& F.Gouverneur, "Systematic review of research on artificial intelligence applications in higher educationwhere are the educators? International Journal of Educational Technology in Higher Education", 1vol.6, no.1, pp.39.

[2] A.Fardinpour, M.M.Pedram \& M.Burkle, "Intelligent learning management systems: Definition, features and measurement of intelligence. International Journal of Distance Education Technologies (IJDET), vol.12, no.4, pp.19-31.

[3] K.Colchester, H.Hagras, D.Alghazzawi \& G.Aldabbagh, "A survey of artificial intelligence techniques employed for adaptive educational systems within e-learning platforms, Journal of Artificial Intelligence and Soft Computing Research, vol.7, no.1, pp.47-64.

[4] V. Kavitha \& R.Lohani, "A critical study on the use of artificial intelligence, e-Learning technology and tools to enhance the learners experience", Cluster Computing, vol.22, no.3, pp.6985-6989, 2019.

[5] S.Rana \& M.Deshmukh, "Artificial Intelligence and Bluetooth Techniques in a Multi-user M-learning Domain. IJCSA, vol.6, no.65, pp.1-13. 2017.

[6] P. Mehta And K. Saroha, "Analysis and Evaluation of Learning Management System Using Data Mining Techniques," 5th ICRTIT, 2016.

[7] D.Dżega \& W.Pietruszkiewicz, "Intelligent decisionmaking support within the e-learning process, In Intelligent and Adaptive Educational-Learning Systems, pp. 497-521, 2013.

[8] L. Tankelevičienè and R. Damaševičius, "Towards the development of genuine intelligent ontology-based eLearning systems," 2010 5th IEEE International Conference Intelligent Systems, London, 2010, pp. 7984.
[9] R.A.Silveira \& M. KNakayama, "An Intelligent Tutoring Systems Integrated with Learning Management Systems. In International Conference on Practical Applications of Agents and Multi-Agent Systems," pp. 316-327, 2013.

[10] W. F. W. Ahmad, and A. S. Hashim, "Enhancement of Learning Management System by Integrating Learning Styles and Adaptive Courses," Advances in Intelligent Systems and Computing, 2017, pp. 211-218.

[11] M. Rau, C. H“osel, C. Roschke, R. Thomanek, and M. Ritter, "Impact of Motivational Factors on the Learning Process in the Use of Learning Management Systems: An Empirical Study Based on Learners' Experiences,' HCII, 2019, pp. 278-283

[12] S. Ghazal, H. Aldowah, and I. Umar, "Critical Factors to Learning Management System Acceptance and Satisfaction in a Blended Learning Environment," Recent Trends in Information and Communication Technology, 2018, pp. 688-698.

[13] N. Cavus, "The evaluation of Learning Management Systems using an artificial intelligence fuzzy logic algorithm", Advances in Engineering Software, vol.41, no.2, pp.248-254, 2010.

[14] J. T. Avella, M. Kebritchi, S. G. Nunn and T. Kanai, "Learning Analytics Methods, Benefits, and Challenges in Higher Education: A Systematic Literature Review," Online Learning, 2016, Vol. 20, Iss. 2.

[15] M. Kuikka, M. Kitola, and M. J. Laakso, "Challenges when introducing electronic exam," Research in Learning Technology, 2014, Vol. 22.

[16] H. Jerković, P. Vranešić, and A. Radan, "Analysis of Learning Management Systems Features and future development challenges in the modern cloud environment," MIPRO, 2016.I

[17] M. T. A., MCA \& P. Yasotha, "Estimation of Student Performance Using Artificial Intelligence with LMS Strategies. Management", vol.10, no.3, 2020.

[18] W. T. Nakamura, L. C. Marques, L. Rivero, E. H. T. de Oliveira, and T. Conte, "Are Generic UX Evaluation Techniques Enough? A study on the UX Evaluation of the Edmodo Learning Management System," CBIE, 2017, pp. 1007-1016.

[19] S. Jung and J. Huh, "An Efficient LMS Platform and Its Test Bed," Journal of Electronics MDPI, 2019.

[20] S. Sivakumar, S.Venkataraman \& C.Gombiro," A userintelligent adaptive learning model for learning management system using data mining and artificial intelligence", 2015

[21] Z. R. Razlighi and S. Ghazi-Maghrebi, "Achieving Better Performance Using a New Variable LMS Algorithm Equalizer for Systems-Based OFDM," 2014 2nd International Conference on Artificial Intelligence, Modelling and Simulation, Madrid, 2014, pp. 329-332.

[22] S. B. Dias, J. A.Diniz \& L. J. Hadjileontiadis, "On Modeling Users' Quality of Interaction with LMS Using Fuzzy Logic", In Towards an Intelligent Learning Management System Under Blended Learning, pp. 151$168,2014$.

[23] C. E. G.Palomino, R. A.Silveira \& M. K. Nakayama, "An intelligent LMS model based on intelligent tutoring 
systems. In International Conference on Intelligent Tutoring Systems, pp. 567-574, 2014.

[24] N. Nenkov, G. Dimitrov, Y. Dyachenko and K. Koeva, "Artificial intelligence technologies for personnel learning management systems," 2016 IEEE 8th International Conference on Intelligent Systems (IS), Sofia, 2016, pp. 189-195.

[25] G. Fenza, F. Orciuoli and D. G. Sampson, "Building Adaptive Tutoring Model Using Artificial Neural Networks and Reinforcement Learning," 2017 IEEE 17th International Conference on Advanced Learning Technologies (ICALT), Timisoara, 2017, pp. 460-462.

[26] S.Keele, "Guidelines for performing systematic literature reviews in software engineering",Technical report, Ver. 2.3 EBSE Technical Report.

[27] R.Bajaj \& V.Sharma, "Smart Education with artificial intelligence based determination of learning styles", Procedia computer science, vol.132, pp.834-842, 2018.

[28] Y. Kim, T. Soyata and R. F. Behnagh, "Towards Emotionally Aware AI Smart Classroom: Current Issues and Directions for Engineering and Education," in IEEE Access, vol. 6, pp. 5308-5331, 2018.

[29] M.Cantabella，R.Martínez-España， B.yuso, J.A.Yáñez, A.Muñoz. "Analysis of student behavior in learning management systems through a Big Data framework", Future Generation Computer Systems, 90, pp.262-272, 2019.

[30] S.E1 Janati, A.Maach \& D.El Ghanami, "SMART Education Framework for Adaptation Content Presentation. Procedia Computer Science, 127, pp.436443, 2018.

[31] H.Singh \& S. J Miah, "Design of a mobile-based learning management system for incorporating employment demands: Case context of an Australian University", Education and Information Technologies, vol.24, no.2, pp. 995-1014, 2019.

[32] M. Ciolacu, A. F. Tehrani, L. Binder and P. M. Svasta, "Education 4.0 - Artificial Intelligence Assisted Higher Education: Early recognition System with Machine Learning to support Students' Success," 2018 IEEE 24th International Symposium for Design and Technology in Electronic Packaging (SIITME), Iasi, 2018, pp. 23-30.

[33] S. Fauvel et al., "Artificial Intelligence Powered MOOCs: A Brief Survey," 2018 IEEE International Conference on Agents (ICA), Singapore, 2018, pp. 5661.

[34] I.Amarasinghe, D.Hernández-Leo \& A.Jonsson, "Datainformed design parameters for adaptive collaborative scripting in across-spaces learning situations", User Modeling and User-Adapted Interaction, vol.29, no.4, pp.869-892, 2019.

[35] S.K.Kim \& J.H.Huh, "A study on the LMS platform performance and performance improvement of k-moocs platform from learner's perspective", In Advanced multimedia and ubiquitous engineering, pp. 781-786, 2018.

[36] V. K. Shukla and A. Verma, "Enhancing LMS Experience through AIML Base and Retrieval Base Chatbot using R Language," 2019 International Conference on Automation, Computational and Technology Management (ICACTM), London, United Kingdom, 2019, pp. 561-567.

[37] W. Villegas-Ch, X. Palacios-Pacheco and S. LujánMora, "Artificial intelligence as a support technique for university learning," 2019 IEEE World Conference on Engineering Education (EDUNINE), Lima, Peru, 2019, pp. 1-6. 